\title{
Are medicinal herbs safe? The opinion of plant vendors from Diadema (São Paulo, southeastern Brazil)
}

\author{
Juliana Lanini," Joaquim M. Duarte-Almeida," Solange A. \\ Nappo, E. A. Carlini
}

Departamento de Psicobiologia, Universidade Federal de São Paulo, Brazil.

Revista Brasileira de Farmacognosia Brazilian Journal of Pharmacognosy 22(1): 21-28, Jan./Feb. 2012

\begin{abstract}
Medicinal plants (MP) have been used world-wide for the treatment or prevention of health conditions and due to their natural origin; they have been historically considered harmless. Semi-structured interviews were carried out with an intentional sample of twenty plant vendors in the city of Diadema to explore their knowledge and beliefs on the safety and efficacy of MP. Different levels of perceptions about the safety of MP were found, varying from "completely safe" to "completely harmful". The majority of the interviewees declared that "if herbs have an effect, they are also likely to have a side effect", depending on many factors such as dosage, concomitant use of other drugs, characteristics of the plant material and consumer related factors, specially those related to pregnant women, children and elderly people. Thirty-nine unexpected events related to 21 species of MP were reported. One case of serious gastrointestinal disease related to the consumption of a contaminated "slim mixture" was also described. Adverse events and other problems that result from MP are relatively uncommon, but they are almost certainly underreported and occur more often than acknowledged. This study strengthens the call for further research and educational efforts into this complex area.
\end{abstract}

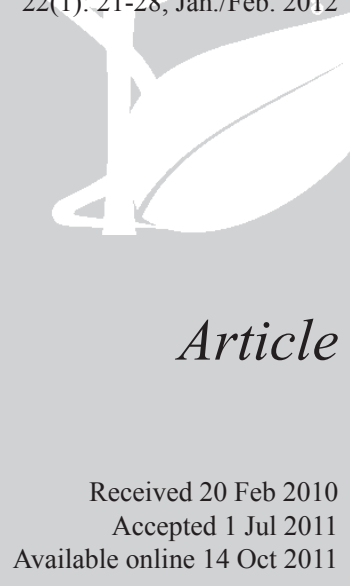

Keywords: medicinal herbs plant vendors qualitative research safety

ISSN 0102-695X http://dx.doi.org/10.1590/S0102$695 \times 2011005000188$

\section{Introduction}

Traditionally, medicinal herbs have been used for the treatment or prevention of health various conditions, ranging from depression to high blood pressure and from skin diseases to diabetes. Many of these herbs are believed to be free of risks and are commonly used for self-medication without supervision. During the last three decades, there has been the most remarkable revival of herbal medicine (Balbino \& Dias, 2010). A further strength of herbal medicines is that they are inexpensive, or at least, cheaper than conventional remedies. World Health Organization estimates that $80 \%$ of people in developing countries rely on traditional herbal medicines (Shaw, 1998).

However, the "naturalness" of medicinal herbs does not guarantee that they are harmless. Toxic potential, consumer-related factors such as age, disease factors, pregnancy (De Smet, 2004), contamination (Ko, 1998), adulteration and lack of regulation (Ernst, 2007) are some of the risk factors deemed to be associated with herbal adverse reactions, poisonings and other complications. Furthermore, interactions with traditional drugs are possible, leading to a lower efficacy of pharmacological treatments or to toxic manifestations (Cuzzolin et al.,
2006). In recent years, adverse events possibly associated with a wide range of herbal remedies have been published elsewhere (Ries \& Sahud, 1975; Arseculeratne et al., 1985; Stickel et al., 2005; Sossai et al., 2007; Balbino \& Dias, 2010).

In most countries, medicinal plants are marketed as dietary supplements and are not subject to the premarketing regulatory clearance required for drugs; additionally, adverse effect monitoring is either nonexistent or inefficient (Ernst 2004). In Brazil, medicinal herbs are freely sold in health food shops, supermarkets and especially by herbal vendors in the streets, fairs or open air markets. The name given to these vendors may vary regionally in Brazil: raizeiro ("root doctors"), erveiro or ervateiro (herbalists). In fact, they serve as a local "doctors" and the general population usually looks for their knowledge to find a "natural cure" for several health conditions (Albuquerque et al., 2007).

The aim of the present study was to explore the knowledge, use, attitudes and beliefs of herbal medicine of an intentional sample of herbal vendors concerning their opinion about safety, restricted use, possible drug interactions and side effects of these therapies. 


\section{Material and Methods}

Considering the aim of this work, which intends to understand the way of thinking of herbal vendors, qualitative research techniques were chosen, through which the phenomenon was identified based on individuals' values, beliefs and representations of vendors (Patton, 2001). This, in the context of this study, constitutes the most appropriate choice of methodology because it allows the understanding of the event starting from the values, behaviour and vision of those who experienced it (WHO, 1994; Patton, 2001).

\section{Local of study}

The research was performed in Diadema, a city located in São Paulo state, Brazil; with around 390,000 inhabitants. Diadema has a large number of migrants from northeastern Brazil, which is known for its tradition of medicinal herbs use (Albuquerque et al., 2007; IBGE 2011). Also, Diadema has a small urban area (31 $\mathrm{km}^{2}$ ), which facilitated the identification and access to interviewees.

\section{Sample}

A purposeful sample composed of twenty herbal vendors was established according to the following criteria: to live in Diadema and to sell medicinal herbs for at least two years; allowing the inclusion of people with a wealthy source of information on the theme.

The subjects were introduced by key-informants - KI(WHO, 1994; Taylor \& Bodgan, 1998), who are people with special knowledge of the study population. The KI facilitated access to the herbal vendors and through their information a guide was elaborated, containing important topics for the comprehension of the theme. This guide was utilised during the interviews.

The sample was then recruited using the snowball technique, in which a respondent indicates the next and so on (Biernacki \& Waldorf, 1981). The sample was constituted by twenty herbal vendors spread over six different chains of vendors. Each chain had an average of 3 or 4 interviewees with similar characteristics intra chains, i.e., belonged to the same social network. However these features were completely different inter chains, i.e., its constituents had no relationship or friendship. This construction ensured the diversity of the sample.

An in-depth semi-structured interview, which lasted an average of $60 \mathrm{~min}$, was performed with each component of the sample (Kvale, 1996), and recorded with the interviewee's prior agreement. The interview was based on the guide and covered the following topics: (1) If the interviewees considered (or not) the herbal plants free of risks, (2) if the interviewees advised the customers about the possible interaction with synthetic drugs, (3) if there are plants of restricted use, (4) if they give information about the "correct" way to use the herbal medicine, (5) socio-demographic characteristics of the participants, and (6) information about serious adverse reactions possibly related to medicinal plants used by themselves or customers. Around the $18^{\text {th }}$ interview, it was noticed that the theory of saturation point had been reached (Paton, 2001; Creswell, 1998; WHO, 1994). In other words, the next interviews began to present redundancy in the thematic categories, because the discourse was no longer contributing additional information.

Each interviewee was identified by an alphanumerical code, based on their name, age, gender, and duration of herbal vendor activity. After the interviews had been transcribed, they were subjected to the pre-analysis and coding stages based on the one proposed by Bardin (2008). Passages of coded discourse were analysed together, making it possible to obtain reports corresponding to each theme of the interview, by aggregating the responses from the twenty interviewees. In this study we used the technique of triangulation in the analysis of results; i.e., besides the principal researcher, other two researchers analyzed the results to identify the consistency of interpretations. This technique reduced the likelihood of misinterpretation leading to more appropriate results. Parts of the vendors 'interviews are presented in italics. Lastly, inferences, interpretations and hypotheses based on the content of the discourse analysis were elaborated (Bardin, 2008).

The study was approved by the Research Ethics Committee of the Federal University of São Paulo (CEP 1803/07)

\section{Results and Discussion}

\section{Socio-demographic data}

The participants included thirteen men and seven women. $50 \%$ of participants had primary school education or less. Four of them were functionally illiterate. Their average age was 55 years old (range from 30 to 90). Most of them were not originally from Diadema, but rather from northeastern regions of Brazil where traditional medicine is largely employed because people cannot afford conventional pharmaceuticals, and also because socio-culturally, folk medicine has a wide acceptance.

Approximately $70 \%$ of the subjects in this study reported that they have learned about herbal therapies from family members, attesting their familiar tradition with medicinal plants. By self report, the knowledge and practice of traditional healing is a family matter and is passed on by inheritance. Almost all of those participants 
who were literate declared that they often consult books and magazines on medicinal plants to remember plant names, indications and manners of use. About $74 \%$ of participants had been selling medicinal plants in Diadema for 10 years or more.

\section{Risk Perception}

The interviewed believed that in spite of medicinal herbs being safer than conventional drugs, they can also cause side-effects. However, the perception of such risks was different among them. They attributed different factors that can trigger side-effects by herbs. Analyzing the content of the interview material, it was concluded that the opinion of the herbal vendors about the safety of medicinal herbs is tied basically to factors associated with: herbs characteristics; sales strategies and beliefs of the herbal vendors; and beliefs of those who consume medicinal herbs. All results are presented respecting these three major divisions and within each one the categories identified are analyzed.

\section{Risks associated to beliefs of herbal consumers}

"Medicinal herbs are drugs"

"As drugs, they can generate either benefit or harm. The effect depends on the dose and the customer's use."

According to the interviewees, the customers believe that medicinal plants are not "remedies", and an increase in the dose will enhance the benefits. This belief can lead to an incorrect, inappropriate or even unnecessary use. This assertion finds support in the literature: in an ethnobotanical survey carried out in an important traditional market in the city of Recife (Pernambuco, northeaster Brazil), the authors reported that herbal vendors themselves recognised that the indiscriminate use of medicinal plants could lead to serious or even fatal accidents (Albuquerque et al., 2007). Lanini et al. (2009) when interviewing medicinal herbal consumers, also highlighted the belief that "what comes from the earth does not harm".

Risks associated to beliefs and seller strategies of the herbal vendors

"Herbs are natural"

"Since they are natural, there are no chemicals, and therefore there are no risks associated".

Just as consumers, these are vendors who also share the belief that if herbs are natural, they are devoid of risks. They add that the lack of "chemistry" associated to their composition makes them safe. To give support to this assertion they invoke God as creator and perfection. The statement below reflects this belief:
"It is much better than the drugs we take because they have no danger. I think that God put here on the Earth is to heal the people... if God created it, we can use without fear".

This belief becomes dangerous since it is used as a marketing strategy to sell such herbs. This "natural marketing" can reinforce the carelessness of consumers about the potential adverse effects arising out of these herbs.

\section{"If I use them and it is good, I prescribe for the others"}

The majority of the interviewees (95\%) reported using herbs themselves throughout their lives and planned to continue using them. The main reasons given for choosing herbal remedies was that they were safer than "drugstore's drugs." They also declared that herbs are as effective as synthetic drugs, although they can demand more time and rigorous discipline from customers in order to yield satisfactory results.

Among the interviewees, $90 \%$ declared that they usually prescribe the plants to be used and the appropriate dosages for each therapeutic end, giving information about the "correct" way to use medicinal plants. The correct use is based on their own experience of using herbs.

"When someone complains about the herb not working, I ask "but how do you prepare it?", because the person usually uses it incorrectly. The big secret is to know how to use them (herbs)."

This vendors' behaviour demonstrates that they believe in their own expertise and "deserve" the title by which they are known: doctors in herbs.

\section{Effective or not, it does not matter, business is business}

Only one participant reported not using medicinal plants himself. According to him, medicinal plants are inefficient as medicines, and any poisoning effect would be extreme, since they are not as "clean" as conventional medicines. This unique case is curious, since the interviewed subject satisfied the inclusion criteria of the study and demonstrated a large knowledge about the subject.

Unlike most, this herb vendor considers his work as a "business" with the aggravating factor that, despite having a negative view of herbs, he sells them to the consumers without taking into consideration his perceptions of safety and efficacy of herbs. The statement below reflects this behaviour. 
"I do not know if is good or not (herbs), but I do not use them. People want to buy, I also want to sell, and business is business".

\section{Risks associated to the herbal characteristics The medicinal herbs are easily adulterated}

The interviewees also reported risks related to unscrupulous manufacturing and selling practices, yielding that traditional herbs might be replaced by toxic ones, resulting in loss of efficacy or unexpected effects. They declared that common names of plants and herbal remedies may be outdated and variable depending on the geographic region, causing a lot of confusion. Since plants are not regulated, there is no guarantee that the herbal material used in preparation of the product is of good quality and correctly identified. Moreover, dosefinding studies are not available for the majority of medicinal plants in use today. More information is also lacking in several areas relevant to safety. According to the interviewees, the only "guarantee" is their knowledge, observations and experiences throughout their lives that have enabled them to recognize the plant's narrow margin of safety and also the importance of dose; and for a successful treatment, their instructions must be followed.

\section{The medicinal herbs works better together}

The interviewees reported that herb-herb interactions may be beneficial and does not represent harm to the customers. According to them, herbs may be used either in their primary forms or combined into complex mixtures, and the correct association of two or more herbs may increase their therapeutic effects, because herbs "work better together".

In fact, many herbal mixtures typically contain two or more medicinal plants, and it is difficult to discover which ingredient is the one responsible for the therapeutic effect, or whether it results from the combination of all of them. For instance, Sinupret ${ }^{\circledR}$ (Bionorica, Germany), the best selling herbal medicinal product in Germany, contains five different medicinal plants. Asian herbal mixtures typically contain about twice that amount (Ernst, 2004).

\section{"Mixing herbs with allopathic medicines we do not know how it works"}

The herb-allopathic association has been assumed as positive only when the herb therapeutic effect would be to attenuate or to abolish synthetic drug side-effects. On the other hand, the interviewees do not encourage the use of medicinal herbs as a complementary treatment when both conventional and alternative treatments have the same purposes. According to the interviewees, concomitant use of herbal and conventional drugs compromises the efficacy of conventional medicines by delaying their activity.

Interviewees also considered the possibility of herb-drug interaction causing unexpected or harmful symptoms, because an herb component may cause either an increase or decrease in the amount of drug in the blood stream.

Contradictory to the herbal vendor's instructions, previous studies showed that the majority of people use medicinal herbs as a complement to conventional therapy, not as an alternative (Eisenberg et al., 1998). Unlike conventional drug-drug interactions, which are usually familiar and predictable, herb-drug and herb-herb interactions are exceedingly difficult to anticipate. Since there is a lack of systematic data, together with a false perception of safety, there may be unrecognized problems related to the association between herbs and conventional drugs. Cytochrome P450 (CYP) monooxygenases are probably the most important classes of enzymes in hepatic drug metabolism (Liu et al., 2006) and the list of herbal medicines with a potential for modifying drug bioavailability by inhibition or stimulation of CYP450 enzymes seems endless. For example, St John's wort increases the activity of the CYP3A4 and may lead to a reduction in plasma concentration of a number of medicines, including cyclosporin, statins and hormonal contraceptives (Novack, 2008).

\section{"Women's friends and children's enemy" - Herbs during the pregnancy}

According to the interviewees, almost every medicine (natural or not) is contraindicated for pregnant women. They consider pregnant women as particular cases, where even "light" herbs must be consumed in lesser doses. In addition to the abortifacient risks of several herbs, they suggested that certain herbs (Table 1) are associated with embryotoxic or fetotoxic effects. They usually call these plants "women's friends and children's enemy".

"We do not recommend anything for pregnant women, just something to relax or to flatulence because in this state (pregnancy) everything is dangerous."

Most surveys agree that women use more alternative medicine than men, and pregnant women felt more attracted to herbs because they are promoted as harmless and free of adverse effects (Lapi et al., 2008). There have been very few formal studies of herbal consumption in pregnancy and even fewer looking at outcomes and side effects (Pinn \& Pallett, 2002; Ruiz et al., 2008). One study showed that many herbal medicine 
products have been associated with risks to pregnant women and their babies (Ernst, 2002a).

Table 1. Medicinal herbs contraindicated for pregnant women.

\begin{tabular}{lll}
\hline Popular name & Scientific name $^{1}$ & Family $^{1}$ \\
\hline Canela & Cinnamomum verum J. Presl. $^{\text {Louro }}$ & Lauraceae \\
Sene & Laurus nobilis L. & Lauraceae \\
Buchinha & Senna alexandrina Mill. & Fabaceae \\
Erva-mate & Luffa operculata (L.) Cogn. & Cucurbitaceae \\
Arruda & Ilex paraguariensis A. St.-Hill & Aquifoliaceae \\
Erva-de-santa-maria & Ruta graveolens L. & Rutaceae \\
Marcela & Egletes viscosa (L.) Less. & Chenopodiaceae \\
Marcela & Achyrocline satureioides (Lam.) DC. & Asteraceae \\
\hline
\end{tabular}

${ }^{1}$ Family and scientific name suggested based in the popular names and their use indications cited during the interviews.

"Everyone can use medicinal herbs, but not everyone can use all herbs"

The interviewees reported that some herbs are very "strong" and must be consumed in lesser doses by children and the elderly; depending on the strength of the herb, in some cases it should never be prescribed for these populations. The quote below gives a vendors idea about this issue:

"It is not advisable to give strong herbs to the children, because their bodies are different from ours. This same rule should also be applied to the elderly. The situation can be worse when the elderly is using controlled medicine while is taking herbs. This association can cause interaction or the effect of synthetic drug can be decreased or interrupted"

In fact, compared with adults, children and the elderly may be at particular risk of experiencing the adverse effects of herbal treatments. The capacity of children and the elderly for detoxifying chemicals may be reduced, and they can experience a dangerous increase in the drug's plasma concentrations. Between 1968 and 1997, the WHO Monitoring Centre received 8,985 case reports of adverse events associated with herbal medicines. About $7.5 \%$ of the patients concerned were 60 years old and older (Ernst, 2002a). Children are especially susceptible to the harmful effects of dosage variation due to their smaller size and lack of some important enzymes (Ernst, 2002b).

\section{Cases report}

Since the present study is a qualitative one, the data showed are based on voluntary reports and not confirmed by physicians. Therefore, although the reported symptoms are certainly relevant, it is difficult to demonstrate the causal link to the medicinal herb consumed, as other explanations are also possible to assess. Furthermore, it was not possible to obtain an adequate identification of the plants related to the cases. Almost every plant in this study is commercialised in a dry, pulverised, or fragmented form, making it very hard to collect identifiable herbarium samples. All the scientific names presented in this study were suggested based on the popular names and their use indications cited during the interviews.

Thirteen interviewees reported 39 unexpected events that were possibly related to 21 species of medicinal herbs (Table 2). The most frequent species reported were "buchinha"- Luffa operculata (L.) Cogn. (seven reports), "sene"- Senna alexandrina Mill. (four reports) and "guaraná"- Paullinia cupana Kunth (three reports). The most frequent unexpected signs and symptoms reported involved the central nervous, gastrointestinal and cardiovascular systems. The manifestations observed with many of the plants described in this research are well documented in the literature (Rang et al., 2004).

The popular "buchinha" was sold in all of the places surveyed as an effective treatment for respiratory diseases such as sinusitis and also as an abortive agent. Among other problems, three deaths were reported with "buchinha". Previous studies showed that this plant is potentially toxic and can cause, among other harmful effects, irritation of the mucous membranes, nausea, abortions, bleeding and embryotoxic protein synthesisinhibiting action (Ngai et al., 1993; Lanini et al., 2009). One recent brazilian study showed that the plant vendors themselves mentioned cases of death from over-ingestion of this plant (Albuquerque et al., 2007).

"Guaraná", which is largely used to improve mental and physical health, contains a substantial amount of caffeine, who might be a possible cause of CNS and cardiovascular effects described in the present work (Cannon et al., 2001; Schmidt \& Karlson-Stiber, 2008).

"Sene" is a natural drug frequently employed as laxative. The interviewees related cases of "hardening" and "collapse" of the intestines and also cases of colonic cancer possibly related with the chronic ingestion of elevated doses of the tea prepared from sene's leaves or fruits. They also reported cases of abortion. Constipation tends to be highly prevalent among pregnant women, and so this population is often at a heightened risk of side effects due to consumption of sene (Schmidt \& Karlson-Stiber, 2008). Sene contains anthraquinones, which possess both abortive and carcinogenic proprieties (Siegers et al., 1993; Keller et al., 2008).

One case (which is not included in the 39 cases cited above), describes one particular lot of a "slim mixture" (mixture of seven medicinal plants used to lose weight) that was contaminated with "fungus". As a consequence of this contamination, a 40-yearold-woman, after ingestion of this tainted preparation, 
Table 2. Medicinal herbs possibly related to harmful signs and symptoms, number of citations for each one, signs and symptoms described.

\begin{tabular}{|c|c|c|c|}
\hline Popular name & Family and scientific name ${ }^{1}$ & Citations number & Signs and symptoms \\
\hline Buchinha & $\begin{array}{l}\text { Cucurbitaceae } \\
\text { Luffa operculata (L.) Cogn. }\end{array}$ & 7 & $\begin{array}{l}\text { Irritation of the mucous membranes, nausea, } \\
\text { abortions, bleeding. }\end{array}$ \\
\hline Sene & $\begin{array}{l}\text { Fabaceae } \\
\text { Senna alexandrina Mill. }\end{array}$ & 4 & Abortion, gastrointestinal disorders \\
\hline Barbatimão & Stryphnodendron barbatiman Mart. & 2 & Anaphylactic reaction \\
\hline Olho-de-boi & Dioclea grandiflora Mart. ex Benth & 1 & Heart rhythm disorders \\
\hline Copaíba & Copaifera langsdorffii Desf. & 1 & Gastrointestinal disorders \\
\hline Guaraná & $\begin{array}{l}\text { Sapindaceae } \\
\text { Paullinia cupana Kunth }\end{array}$ & 3 & CNS effects, heart rate and rhythm disorders \\
\hline Pau-tenente & $\begin{array}{l}\text { Simaroubaceae } \\
\text { Quassia amara } \mathrm{L} .\end{array}$ & 3 & Heart rate and rhythm disorders \\
\hline Amora & $\begin{array}{l}\text { Moraceae } \\
\text { Morus nigra L. }\end{array}$ & 2 & High blood pressure \\
\hline Alecrim & $\begin{array}{l}\text { Lamiaceae } \\
\text { Rosmarinus officinalis L. }\end{array}$ & 2 & Contraceptive effect \\
\hline Guiné & $\begin{array}{l}\text { Phytolaccaceae } \\
\text { Petiveria alliacea } \mathrm{L} \text {. }\end{array}$ & 2 & CNS effects \\
\hline Chá-verde & $\begin{array}{l}\text { Theaceae } \\
\text { Camellia sinensis (L.) Kuntze }\end{array}$ & 2 & $\begin{array}{l}\text { Headache, tachycardia, gastrointestinal } \\
\text { disorders }\end{array}$ \\
\hline Endro & $\begin{array}{l}\text { Apiaceae } \\
\text { Anethum graveolens L. }\end{array}$ & 1 & Contact dermatitis \\
\hline Carambola & $\begin{array}{l}\text { Oxalidaceae } \\
\text { Averrhoa carambola } \mathrm{L} \text {. }\end{array}$ & 1 & Insomnia, headache, CNS disorders \\
\hline Losna & $\begin{array}{l}\text { Asteraceae } \\
\text { Artemisia absinthium L. }\end{array}$ & 1 & Headache, nausea, CNS disorders \\
\hline Stévia & Stevia rebaudiana Bertoni (Bertoni) & 1 & Contraceptive effect \\
\hline Abacate & $\begin{array}{l}\text { Lauraceae } \\
\text { Persea americana Mill. }\end{array}$ & 1 & Urinary incontinence \\
\hline Erva-de-santa-maria & $\begin{array}{l}\text { Chenopodiaceae } \\
\text { Chenopodium ambrosioides L. }\end{array}$ & 1 & Abortion \\
\hline Mate & $\begin{array}{l}\text { Aquifoliaceae } \\
\text { Ilex paraguariensis A. St.-Hill }\end{array}$ & 1 & Abortion \\
\hline Erva-doce & $\begin{array}{l}\text { Umbelífera } \\
\text { Pimpinella anisum } \mathrm{L} \text {. }\end{array}$ & 1 & Hypotensive effects \\
\hline Cipó-mil-homens & $\begin{array}{l}\text { Aristolochiaceae } \\
\text { Aristolochia triangularis Chan. }\end{array}$ & 1 & Headache, CNS effects \\
\hline Boldo & $\begin{array}{l}\text { Monimiaceae } \\
\text { Peumus boldus Molina }\end{array}$ & 1 & Hallucination \\
\hline
\end{tabular}

${ }^{1}$ Family and scientific name suggested based in the popular names and their use indications cited during the interviews.

was hospitalised with serious gastrointestinal diseases. According to the interviewee, the herbal material was not "dry enough"; but he was not able to recognise that the material was not good for use. Several surveys show the problems related with medicinal herbs contaminated with a myriad of things, from heavy metals to virtually every kind of impurity (Ko 1998; Mascolo et al., 1999; Ferrante et al., 2007; Melo et al., 2007). 


\section{Final considerations}

The interviewed showed different levels of perceptions about medicinal herbs safety, varying from "completely safe" to "completely harmful". In this study, there were identified herb risks associated to: beliefs of herbal consumers; herbal characteristics and beliefs and seller strategies of the herbal vendors. However, the majority of the interviewees declared that if plants have a therapeutic effect, they are also likely to have "side" effects, depending on many factors. Although the present study, by its own characteristics, failed to obtain the correct identification of the plants involved, the information obtained is clearly of interest to health care providers, and more importantly, our study strengthens the call for more research and educational efforts into this area.

Adverse events and other problems that result from "natural" medicines are relatively uncommon, but they are almost certainly underreported and occur more often than acknowledged. Medicinal plants are traditionally considered as innocuous, but as they are commonly commercially available, they require sanitary surveillance in order to identify their risks, to give them a legal status, to evaluate their efficacy and to ascertain their safety.

\section{Acknowledgements}

The authors are sincerely thankful to the interviewees who were essential to this study and also to AFIP, CNPq and FAPESP for the financial support.

\section{References}

Albuquerque UP, Monteiro JM, Ramos MA, Amorim ELC 2007. Medicinal and magic plants from a public market in northeastern Brazil. J Ethnopharmacol 110: 76-91.

Arseculeratne SN, Gunatilaka AAL, Panabokke RG 1985. Studies on medicinal plants of Sri Lanka Part 14: Toxicity of some traditional medicinal. $J$ Ethnopharmacol 13: 323-335

Balbino EE, Dias MF 2010. Farmacovigilância: um passo em direção ao uso racional de plantas medicinais e fitoterápicos. Rev Bras Farmacogn 20: 992-1000.

Bardin L 2008. Análise de conteúdo. Lisboa: Edições 70.

Biernacki P, Waldorf D 1981. Snowball Sampling: Problems and Techniques of Chain Referral Sampling. Sociol Method Res 10: 141-163.

Cannon ME, Cooke CT, McCarthy JS 2001. Caffeine-induced cardiac arrhythmia: An unrecognized danger of health food products. Med J Australia 174: 520-521.

Creswell JW 1998. Qualitative inquiry and research design: choosing among five traditions. Thousand Oaks: Sage Publications.
Cuzzolin L, Zaffani S, Benoni G 2006. Safety implications regarding use of phytomedicines. Eur J Clin Pharmacol 62: 37-42.

De Smet PAGM 2004. Health risks of herbal remedies: An update. Clin Pharmacol Ther 76: 1-17.

Eisenberg DM, Davis RB, Ettner SL, Appel S, Wilkey S, Van Rompay M, Kessler RC 1998. Trends in alternative medicine use in the United States, 1990-1997: results of a follow-up national survey. J Am Med Assoc 280: 1569-1575.

Ernst E 2002a. Herbal medicinal products during pregnancy: are they safe? Bjog-Int J Obstet Gy 109: 227-235.

Ernst E 2002b. Adverse effects of unconventional therapies in the elderly: a systematic review of the recent literature. J Am Aging Assoc 25: 11-20.

Ernst E 2004. Challenges for phytopharmacovigilance. Postgrad Med J 80: 249-250.

Ernst E 2007. Herbal medicines: Balancing benefits and risks. Novartis Fdn Symp 282: 154-167.

Ferrante LMS, Mayer B, Vasconcelos EC, Oliveira CMR. 2007. GC/FID-based authentication of Baccharis trimera: a quality control study of products commercialized in Curitiba and metropolitan region (Brazil). Rev Bras Farmacogn 17: 356-360.

IBGE 2011. Instituto Brasileiro de Geografia e Estatística. http://www.ibge.gov.br, accessed July 2011.

Keller J, Frederking D, Layer P 2008. The spectrum and treatment of gastrointestinal disorders during pregnancy. Nat Clin Pract Gastr 5: 430-443.

Ko RJ 1998. Adulterants in Asian patent medicines. $N$ Engl $J$ Med 339: 847.

Kvale S 1996. InterViews: an introduction to qualitative research interviewing. Thousand Oaks: Sage Publications.

Lanini J, Duarte-Almeida JM, Nappo SA, Carlini EA 2009. "Natural and therefore free of risks" - adverse effects, poisonings and other problems related to medicinal herbs by "raizeiros" in Diadema/SP". Rev Bras Farmacogn 19: 121-129.

Lapi F, Vannacci A, Moschini M, Cipollini F, Morsuillo M, Gallo E, Banchelli G, Cecchi E, Di Pirro M, Giovanni MG, Cariglia MT, Gori L, Firenzuoli F, Mugelli A 2008. Use, Attitudes and Knowledge of Complementary and Alternative Drugs (CADs) Among Pregnant Women: a Preliminary Survey in Tuscany. Evid Based Compl Alt 5: 1-10.

Liu KH, Kim MJ, Jeon BH, Shon JH, Cha I J, Cho KH, Lee SS, Shin JG 2006. Inhibition of human cytochrome $\mathrm{P} 450$ isoforms and NADPH-CYP reductase in vitro by 15 herbal medicines, including Epimedii herba. J Clin Pharm Ther 31: 83-91.

Mascolo N, Mereto E, Borrelli F, Orsi P, Sini D, Izzo AA, Massa B, Boggio M, Capasso F 1999. Does senna extract promote growth of aberrant crypt foci and malignant tumors in rat colon? Digest Dis Sci 44: 2226-2230. 
Melo JG, Martins JDGR, Amorim ELC, Albuquerque UP 2007. Qualidade de produtos a base de plantas medicinais comercializados no Brasil: castanha-da-índia (Aesculus hippocastanum L.), capim-limão (Cymbopogon citratus (DC.) Stapf) e centela (Centella asiatica (L.) Urban). Acta Bot Bras 21: 27-36.

Ngai TB, Chan WY, Yeung HW 1993. The ribosomeinactivating, antiproliferative and teratogenic activities and immunoreactivities of a protein from seeds of Luffa aegyptiaca (Curcubitaceae). Gen Pharmacol 24: 655658.

Novack R 2008.Review Article: Cytochrome P450 enzyme, and transport protein mediated herb-drug interactions in renal transplant patients: Grapefruit juice, St John's Wort - and beyond! Nephrology 13: 337-347.

Patton MQ 2001. Qualitative research \& evaluation methods. London: Sage Publications.

Pinn G, Pallett L 2002. Herbal medicine in pregnancy. Complement Ther Nurs Midwifery 8: 77-80.

Rang HP, Dale MM, Ritter JM, Moore PK 2004. Farmacologia. Rio de Janeiro: Elsevier.

Ries CA, Sahud MA 1975. Agranulocytosis caused by Chinese herbal medicines. Dangers of medications containing aminopyrine and phenylbutazone. J Am Med Assoc 231: 352-355.

Ruiz ALTG, Taffarello D, Souza VHS, Carvalho JE 2008. Farmacologia e toxicologia de Peumus boldus e
Baccharis genistelloides. Rev Bras Farmacogn 18: 295-300.

Schmidt A, Karlson-Stiber C 2008. Caffeine poisoning and lactate rise: an overlooked toxic effect? Acta Anaesth Scand 52: 1012-1014.

Shaw D 1998. Risks or remedies? Safety aspects of herbal remedies in the UK. J Roy Soc Med 91: 294-296.

Siegers CP, von Hertzberg-Lottin E, Otte M, Schneider B 1993. Anthranoid laxative abuse - a risk for colorectal cancer? Gut 34: 1099-1101.

Sossai P, Nasone C, Cantalamessa, F 2007. Are Herbs Always Good for You? A Case of paralytic Ileum using a herbal tisane. Phytother Res 21: 587-588.

Stickel F, Patsenker E, Schuppan D 2005. Herbal hepatotoxicity. $J$ Hepatol 43: 901-910.

Taylor SJ, Bodgan R. 1998. Introduction to Qualitative Research Methods. New York: John Wiley \& Sons Inc., 1998; 337 p.

World Health Organization 1994. Qualitative research for health programmes. Geneva.

\section{*Correspondence}

Juliana Lanini, Joaquim M. Duarte-Almeida Universidade Federal de São Paulo

Rua Botucatu 862, 04023-062, São Paulo, SP, Brazil. julianalanini@psicobio.epm.br/maudal@usp.br Tel: +55 112149 0155; 50842793 